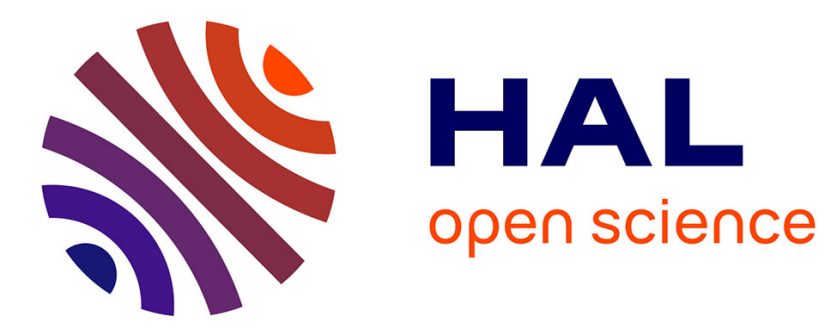

\title{
On the pressure dependence of superconductivity in transition metal dichalcogenide layer crystals
}

\author{
J. Friedel
}

\section{To cite this version:}

J. Friedel. On the pressure dependence of superconductivity in transition metal dichalcogenide layer crystals. Journal de Physique Lettres, 1975, 36 (11), pp.279-280. 10.1051/jphyslet:019750036011027900 . jpa-00231208

\section{HAL Id: jpa-00231208 https://hal.science/jpa-00231208}

Submitted on 1 Jan 1975

HAL is a multi-disciplinary open access archive for the deposit and dissemination of scientific research documents, whether they are published or not. The documents may come from teaching and research institutions in France or abroad, or from public or private research centers.
L'archive ouverte pluridisciplinaire HAL, est destinée au dépôt et à la diffusion de documents scientifiques de niveau recherche, publiés ou non, émanant des établissements d'enseignement et de recherche français ou étrangers, des laboratoires publics ou privés. 


\title{
ON THE PRESSURE DEPENDENCE OF SUPERCONDUCTIVITY IN TRANSITION METAL DICHALCOGENIDE LAYER CRYSTALS
}

\section{J. FRIEDEL}

\author{
Physique des Solides, Université Paris-Sud, Laboratoire associé au C.N.R.S., 91405 Orsay, France
}

(Reçu le 29 août 1975, accepté le 8 septembre 1975)

\begin{abstract}
Résumé. - Les données expérimentales actuelles dans ce domaine suggèrent que les fortes températures critiques sont dues à de fortes densités électroniques au niveau de Fermi plutôt qu’à des modes de phonons mous.
\end{abstract}

Abstract. - Present evidence in this field suggests that high critical temperatures are due to large electronic densities at the Fermi level rather than to soft phonon modes.

Recent measurements of the pressure dependence of superconductivity in transition metal dichalcogenide layer crystals have shown different behaviour in sulfur and selenium compounds [1].

In both $2 \mathrm{H} \mathrm{Nb} \mathrm{S}_{2}$ and $3 \mathrm{R} \mathrm{Nb} \mathrm{S}_{2}$, the critical temperature $T_{\mathrm{c}}$ and the critical field $H_{\mathrm{c} 2}$, show very little variation with pressure, at least up to $10 \mathrm{kbar}$ (Fig. $1 a$, b).

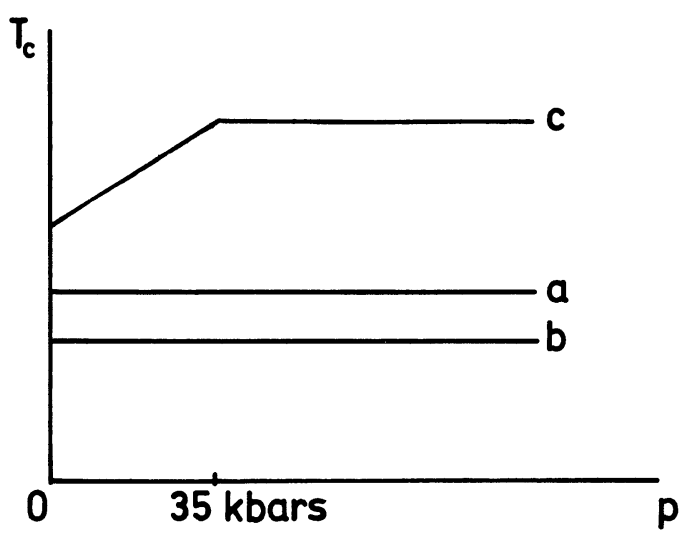

Fig. 1. - Pressure dependence of the critical temperature $T_{\mathrm{c}}$ in transition metal dichalcogenide layer compounds (schematic) : a) $\left.2 \mathrm{H} \mathrm{Nb} \mathrm{S} \mathrm{N}_{2} ; b\right) 3 \mathrm{R} \mathrm{Nb} \mathrm{S}$; c) $2 \mathrm{H} \mathrm{Nb} \mathrm{Se}$.

In $2 \mathrm{H} \mathrm{Nb} \mathrm{Se}{ }_{2}$, the critical temperature $T_{\mathrm{c}}$ increases rapidly with pressure up to $35 \mathrm{kbar}$, then shows little variation with pressure up to $140 \mathrm{kbar}$ (Fig. 1c). $H_{\mathrm{c} 2}$ increases with pressure in the low pressure range (measured up to $13 \mathrm{kbar}$ ), when measured both parallel and perpendicular to the layers.

The high value and pressure variation of $T_{\mathrm{c}}$ in the Se compound have been related to the fact that it exhibits a low temperature phase transformation which is clearly due to a Peierls instability, i.e. on cooling down, the electron-phonon couplings stabilizes a new phase which opens gaps at the Brillouin zone boundary near to the Fermi surface of the high temperature phase [2].

We want to suggest here that the superlattice phase disappears above $35 \mathrm{kbar}$, leaving the undistorted phase, as observed in the sulfur compound. This is strongly suggested by the constancy of $T_{\mathrm{c}}$ above 35 kbars. It would of course be of interest to check this directly or by a study of transport properties.

If this suggestion is right, it should allow the contribution of soft phonon modes and a high electronic density at the Fermi level to the high $T_{\mathrm{c}}^{\prime}$ s to be distinguished.

1) The existence of a large and pressure independent $T_{\mathrm{c}}$ in the Se compound over a very large range of pressures where the superlattice phase would be unstable would rule out the soft phonon modes associated with such a phase as responsible for high $T_{\mathrm{c}}^{\prime}$ s. Indeed it is difficult to believe that any phonon mode could remain in the soft critical state over such a large range of pressures. It looks therefore extremely probable that the high $T_{\mathrm{c}}$ observed in the Se phase above $35 \mathrm{kbar}$ is to be related to a large density of electronic states at the Fermi level $N\left(E_{\mathrm{p}}\right)$. Indeed one expects a narrower $d$ band, thus a larger value of $N\left(E_{\mathrm{F}}\right)$ in the Se compound than in the $\mathrm{S}$ ones, because the larger atomic radii of Se compared with $S$ induce the $\mathrm{Nb}$ atoms to be further apart, both within metallic planes and between metallic planes.

2) The creation of the superlattice phase lowers $T_{\mathrm{c}}$. This is difficult to understand on a soft phonon mode picture, where a minimum of $T_{\mathrm{c}}$ should be expected when the superlattice phase just disappears under pressure, thus tentatively at $35 \mathrm{kbars}$. It is again very 
easy to understand if $T_{\mathrm{c}}$ is related more to $N\left(E_{\mathrm{F}}\right)$ : one knows that the superlattice phases become stable because, by opening gaps at Brillouin zone boundaries near to Fermi surfaces, they lower the average electronic energy in increasing $N(E)$ below $E_{\mathrm{F}}$ at the expense of $N\left(E_{\mathrm{F}}\right)$ (Fig. 2).

The effect of pressure in the Se compound is thus likely to be initially to increase $N\left(E_{\mathrm{F}}\right)$ by reducing the gaps at some Brillouin zone boundaries, owing to a reduction in strength of the superstructure due to Peierls instability.
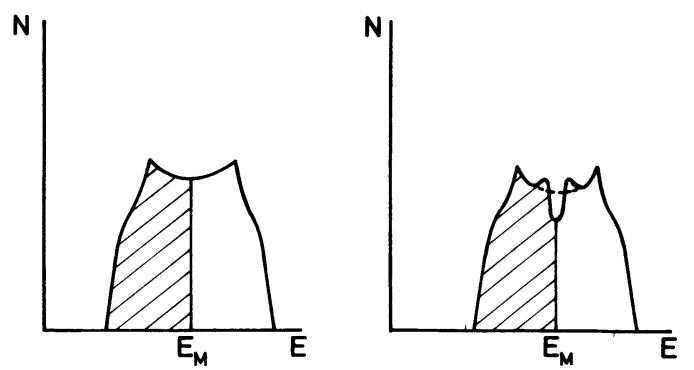

Fig. 2. - Density of states of the $\mathrm{d}$ band (schematic) : a) normal undistorted phase; $b$ ) superlattice phase.

\section{References}

[1] Molinié, P., Jérome, D. and Grant, A. J., Phil. Mag. 30 (1974) [2] Wilson, J. A., Di Salvo, F. J. and Mahajan, S., Adv. Phys. 1091. 24 (1975) 117 